\title{
PERILAKU KELUARGA DALAM PENCEGAHAN PENULARAN COVID-19 PADA BALITA DI DESA POH BERGONG
}

\author{
Ketut Espana Giri \\ Universitas Pendidikan Ganesha \\ (panaprabawa@gmail.com)
}

\begin{abstract}
ABSTRAK
Balita mempunyai hak untuk tumbuh dan berkembang meskipun dalam situasi pandemi. Keuarga terutama orang tua harus tetap bekerja untuk memenuhi kebutuhan balita. Penelitian ini bertujuan untuk menganalisis perilaku keluarga dalam pencegahan penularan Covid-19 pada balita di Desa Poh Bergong. Metode penelitian ini adalah desain cross-sectional. Data dikumpulkan dengan wawancara dan pemberian kuisioner pada orang tua yang memiliki balita dan datang ke posyandu, yaitu sebanyak 75 responden. Data dianalisis dengan descriptive statistics menggunakan SPSS. Hasil penelitian diperoleh bahwa sebagian besar keluarga yang memiliki balita di Desa Poh Bergong sudah menggunakan masker dengan benar, sudah mencuci tangan setiap datang dari luar rumah, mandi dan ganti baju setelah bekerja, tidak langsung menyentuh/menggendong anak setelah bekerja, mengkonsumsi vitamin dan makan makanan bergizi setiap hari. Hal ini membuktikan bahwa orang tua di Desa Poh Bergong mempunyai perilaku baik dalam melakukan pencegahan penularan Covid-19 kepada balita.
\end{abstract}

Kata kunci : Balita, Perilaku, Covid-19

ABSTRACT
Toddlers have the right to grow and develop even in a pandemic situation.Families, especially parents, must continue to work to meet the needs of toddlers.This study aims to analyze family behavior in preventing the transmission of Covid-19 in Toddlers in Poh Bergong Village.The research method used is a crosssectional design.Data was collected by means of interviews and questionnaires to parents who have toddlers who come to the posyandu as many as 75 respondents. Data were analyzed multivariately using SPSS.The results showed that most families with toddlers in Poh Bergong Village had used masks correctly, had washed their hands every time they came from outside the house, showered and changed clothes after work, did not directly touch/hold their children after work, consume vitamins and eat food. nutritious every day.This proves that parents in Poh Bergong Village have good behavior in preventing the transmission of Covid-19 to toddlers.

Keywords : Toddler, Behavior, Covid-19

\section{PENDAHULUAN}

Salah satu tahapan pada anak adalah masa balita, yaitu masa dimana usia anak antara 1-5 tahun. Pada usia ini sangat penting dalam kehidupan manusia, karena anak memiliki rasa ingin tahu terhadap suatu hal, baik dilihat ataupun didengar. Anak memerlukan kesempatan tumbuh dan berkembang dengan normal baik. secara rohani maupun jasmani. 
Anak tidak hanya membutuhkan pengasuh, namun juga membutuhkan pendidikan untuk mengoptimalkan perkembangannya. Tidak hanya kebutuhan sandang yang dibutuhkan oleh anak. Anak juga membutuhkan bimbingan dan kasih sayang dari orang tuanya (Soetjiningsih dan Ranuh, 2013).

Pandemi Covid-19 sudah ditetapkan menjadi ancaman di seluruh dunia termasuk di Indonesia (WHO, 2019). Pemerintah Indonesia terus mengeluarkan aturan Pemberlakuan Pembatasan Kegiatan Masyarakat (PPKM) untuk mengatur aktivitas masyarakat. Setiap orang diminta mengurangi aktivitas diluar rumah, sedangkan orang tua harus tetap bekerja guna memenuhi kebutuhan hidup keluarga. Pandemi ini mengharuskan masyarakat merubah perilaku kesehatannya seperti menggunakan masker dengan baik dan benar, rajin mencuci tangan di air mengalir, menghindari kerumunan dan mengurangi mobilitas. Setelah pulang kerja atau aktivitas di luar rumah, tidak sedikit para orang tua yang melakukan kontak langsung kepada keluarga terutama anak-anaknya, seperti himbauan Pemerintah Provinsi Bali (2020) salah satunya adalah dengan membersihkan diri (mandi dengan menggunakan sabun) dan mengganti pakaian sebelum kontak dengan anggota keluarga terutama anak. Selain itu juga membersihkan barang-barang yang digunakan seperti kaca mata, tas, handphone ataupun barang lain dengan cairan desinfektan.

Ikatan Dokter Anak Indonesia (IDAI) tahun 2020 menyatakan bahwa terdapat 11.000 anak Indonesia yang terpapar virus Covid-19, dengan tingkat kematian anak dibawah usia 1 bulan (13\%), usia sampai 1 tahun (23\%), dan usia anak 1-5 tahun (24\%). Di Provinsi Bali, semenjak masuknya kasus hingga bulan Juli 2020 telah terjadi 89 anak yang terpapar Covid19 dan usia anak 0-5 tahun tercatat 26 anak yang positif Covid-19 (Dinkes Pemprov Bali, 2020).

Covid-19 pada anak tentunya ditularkan oleh orang dewasa yang tinggal satu atap dengan anak. Orang tua harus mengetahui kalau anaknya mempunyai komorbid, dan harus lebih berhati-hati. Setiap orang memiliki risiko terinfeksi Covid-19 tanpa gejala, sehingga setiap orang tua dapat menularkan infeksi kepada anak dan keluarganya.

Penelitian ini bertujuan untuk menganalisis perilaku keluarga dalam pencegahan penularan Covid-19 pada Balita di Desa Poh Bergong Wilayah Kerja Puskesmas Buleleng III. Diharapkan agar orang tua memperhatikan perilaku kesehatan dalam mengasuh balita.

\section{METODE PENELITIAN}

Penelitian ini merupakan penelitian pendekatan cross sectional, dengan jumlah responden sebanyak 75 orang yang memiliki balita dan datang ke posyandu. 
Responden diberikan kuisioner tentang perilaku keluarga dalam mencegah penularan Covid-19. Data diolah berskala nominal, dianalisis menggunakan descriptive statistics.

\section{HASIL DAN PEMBAHASAN}

a. Karakteristik Responden

Tabel 1.3

Karakteristik Responden Berdasarkan Usia Ibu

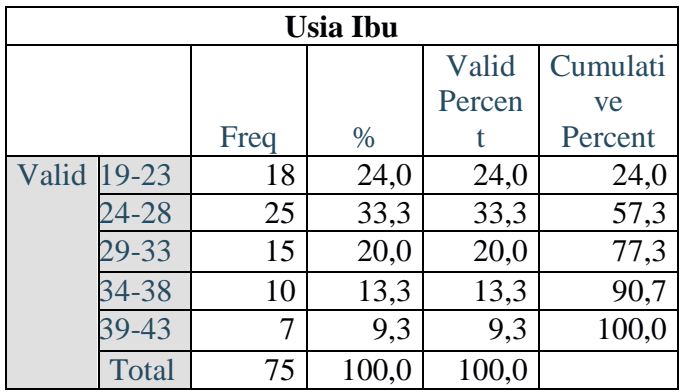

Berdasarkan tabel 1.3 dapat diketahui bahwa dari 75 responden, usia ibu yang menjadi responden paling banyak adalah usia 24-28 tahun yaitu sebanyak 25 orang $(33,3 \%)$. Usia reproduksi yang sehat menurut BKKBN (2012) adalah usia 20-28 tahun. Mengacu BKKBN, usia responden dalam penelitian ini termasuk dalam kategori usia reproduksi sehat. Usia merupakan salah satu faktor yang mempengaruhi perilaku kesehatan. Begitupula menurut Verawati dalam Widyana (2015) bahwa kedewasaan seorang ibu secara fisik maupun mental sangat penting karena akan berpengaruh pada pola asuh dan perkembangan anak.
Tabel 1.4

Karakteristik Responden Berdasarkan Pekerjaan

\begin{tabular}{|l|l|r|r|r|r|}
\hline \multicolumn{2}{|c|}{ Pekerjaan } \\
\hline \multicolumn{2}{|c|}{} & Freq & \multicolumn{1}{c|}{$\%$} & $\begin{array}{c}\text { Valid } \\
\text { Percent }\end{array}$ & $\begin{array}{c}\text { Cumula } \\
\text { tive } \\
\text { Percent }\end{array}$ \\
\hline \multirow{6}{*}{ Valid } & IRT & 51 & 68,0 & 68,0 & 68,0 \\
\cline { 2 - 6 } & $\begin{array}{l}\text { Peg. } \\
\text { Swasta }\end{array}$ & 4 & 5,3 & 5,3 & 73,3 \\
\cline { 2 - 6 } & Pedagang & 3 & 4,0 & 4,0 & 77,3 \\
\cline { 2 - 6 } & Buruh & 7 & 9,3 & 9,3 & 86,7 \\
\cline { 2 - 6 } & Wiraswasta & 8 & 10,7 & 10,7 & 97,3 \\
\cline { 2 - 6 } & PNS & 1 & 1,3 & 1,3 & 98,7 \\
\cline { 2 - 6 } & Petani & 1 & 1,3 & 1,3 & 100,0 \\
\cline { 2 - 6 } & Total & 75 & 100,0 & 100,0 & \\
\hline
\end{tabular}

Dari hasil penelitian tabel 1.4 diketahui bahwa pekerjaan responden yang paling banyak adalah sebagai ibu rumah tangga (IRT), yaitu 51 orang (68\%). IRT memiliki waktu lebih banyak dalam mengurus anak dan mereka lebih jarang berinteraksi dengan orang lain, sehingga mereka akan lebih memperhatikan perilaku kesehatan keluarga dalam mencegah penularan Covid-19. Penelitian Darmawan (2016) menyebutkan bahwa pekerjaan ibu sebagai ibu rumah tangga cenderung memiliki perilaku baik terhadap posyandu untuk memeriksakan kesehatan anaknya, hal ini disebabkan karena waktu yang dimiliki oleh ibu yang tidak bekerja lebih banyak daripada ibu yang bekerja dalam mengurus anak. 
Tabel 1

Karakteristik Responden Berdasarkan Pendidikan ibu

\begin{tabular}{|c|c|c|c|c|c|}
\hline \multicolumn{6}{|c|}{ Pendidikan } \\
\hline & & Freq & $\%$ & $\begin{array}{l}\text { Valid } \\
\text { Percent }\end{array}$ & $\begin{array}{l}\text { Cumula } \\
\text { tive } \\
\text { Percent }\end{array}$ \\
\hline \multirow[t]{7}{*}{ Valid } & $\begin{array}{l}\text { Tidak } \\
\text { Sekolah }\end{array}$ & 1 & 1,3 & 1,3 & 1,3 \\
\hline & SD & 35 & 46,7 & 46,7 & 48,0 \\
\hline & SLTP & 17 & 22,7 & 22,7 & 70,7 \\
\hline & SMU & 17 & 22,7 & 22,7 & 93,3 \\
\hline & Akademi & 1 & 1,3 & 1,3 & 94,7 \\
\hline & Sarjana & 4 & 5,3 & 5,3 & 100,0 \\
\hline & Total & 75 & 100,0 & 100,0 & \\
\hline
\end{tabular}

Pada tabel 1 dapat dilihat bahwa sebagian besar responden berpendidikan SD yaitu 35 orang $(46,7 \%)$. Pendidikan responden dapat mempengaruhi penerimaan informasi. Menurut Notoatmodjo (2014) menyatakan bahwa partisipasi dan peran serta masyarakat dalam berperilaku dipengaruhi oleh tingkat pendidikan.

Tabel 2.

Karakteristik Responden Berdasarkan Anggota Keluarga yang Pernah Sakit Covid-19

\begin{tabular}{|c|c|c|c|c|c|}
\hline \multicolumn{6}{|c|}{ Kena_covid } \\
\hline & & Freq & $\%$ & $\begin{array}{c}\text { Valid } \\
\text { Percent }\end{array}$ & $\begin{array}{l}\text { Cumula } \\
\text { tive } \\
\text { Percent }\end{array}$ \\
\hline \multirow[t]{3}{*}{ Valid } & $\begin{array}{l}\text { Kena } \\
\text { Covid }\end{array}$ & 1 & 1,3 & 1,3 & 1,3 \\
\hline & Tidak & 74 & 98,7 & 98,7 & 100,0 \\
\hline & Total & 75 & 100,0 & 100,0 & \\
\hline
\end{tabular}

Tabel 2 dapat dilihat bahwa anggota responden ada yang pernah terkena Covid19 yakni 1 orang $(1,3 \%)$ dan saat ini sudah sembuh dan dalam keadaan sehat. Satgas Covid-19 Pengurus Besar IDI mengatakan bahwa sumber penularan klaster keluarga diawali oleh salah satu anggota keluarga yang terkena Covid-19 karena adanya anggota keluarga yang masih keluar rumah.
Sebagai kepala keluarga, suami responden bekerja di luar rumah dan sering bertemu orang lain. Apabila ada salah satu anggota keluarga yang terindikasi Covid-19, terdapat dua langkah awal yang bisa dilakukan yaitu memberikan obat sesuai gejala yang dirasakan dan segera ke fasilitas kesehatan. Data IDAI juga menunjukkan bahwa keluarga yang tinggal dengan balita dan lansia merupakan kelompok yang paling rentan terinfeksi Covid-19 dan banyak yang meninggal. Ini terjadi sekitar $60 \%$ keluarga yang ada di Indonesia.

b. Perilaku Keluarga

Tabel 3.

Perilaku Keluarga Terhadap Pencegahan Penularan Covid-19

\begin{tabular}{|c|c|c|c|c|c|}
\hline \multicolumn{6}{|c|}{ Skor } \\
\hline & & Freq & $\%$ & $\begin{array}{l}\text { Valid } \\
\text { Percent }\end{array}$ & $\begin{array}{l}\text { Cumula } \\
\text { tive } \\
\text { Percent }\end{array}$ \\
\hline \multirow[t]{3}{*}{ Valid } & Baik & 40 & 53,3 & 53,3 & 53,3 \\
\hline & $\begin{array}{l}\text { Tidak } \\
\text { baik }\end{array}$ & 35 & 46,7 & 46,7 & 100,0 \\
\hline & Total & 75 & 100,0 & 100,0 & \\
\hline
\end{tabular}

Dari hasil penelitian, perilaku dari 75 responden sebagian besar berperilaku baik dalam pencegahan penularan Covid-19. Menggunakan masker setiap keluar rumah, mencuci tangan setelah datang dari bekerja atau dari luar rumah, tidak menggendong/mendekati balita bila datang dari bekerja, mengkonsumsi vitamin, mengkonsumsi makanan dan minuman bergizi, melakukan olahraga dan membersihkan alat-alat yang digunakan dengan cairan desinfektan bila dari luar rumah. Faktor-faktor yang mempengaruhi perilaku menurut Notoatmodjo (2014) 
adalah faktor makanan dan minuman, faktor perilaku kebersihan diri sendiri, faktor perilaku kebersihan lingkungan, faktor perilaku sakit dan penyakit, dan faktor keseimbangan antar kegiatan istirahat dan olah raga.

Faktor makanan dan minuman terdiri dari kebiasaan makan pagi, pemilihan jenis makanan, jumlah makanan dan minuman, serta kebersihan makanan. Pada faktor keseimbangan antara kegiatan istirahat dan olah raga terdiri dari banyaknya waktu istirahat, aktivitas dirumah dan olah raga teratur.

Dominski (2020) menyatakan bahwa olahraga atau aktivitas fisik sebagai bagian dari PHBS merupakan hal yang sangat penting dimasa pandemi Covid-19. Olahraga atau aktivitas fisik pada intensitas dan durasi sedang dapat mendukung respon imun dan meningkatkan daya tahan tubuh terhadap penyakit, dan ini dapat dilakukan didalam dan diluar ruangan.

\section{KESIMPULAN DAN SARAN}

Berdasarkan hasil penelitian dan pembahasan, maka dapat dibuatkan simpulan dari penelitian ini yaitu perilaku keluarga dalam melakukan pencegahan penularan Covid-19 termasuk dalam kategori baik. Bagi masyarakat diharapkan untuk terus meningkatkan perlindungan diri dalam pencegahan penularan Covid-19 ini dilihat dari adanya anggota keluarga yang terkena Covid-19, menjaga kesehatan diri sendiri karena sampai saat ini pandemi masih berlangsung dengan terjadinya peningkatan kasus di berbagai daerah.

\section{DAFTAR PUSTAKA}

BKKBN. 2012. Kajian Pernikahan Usia Dini. Jakarta.

Darmawan, Ngurah. 2016. Faktor-faktor Yang Mempengaruhi Perilaku Kunjungan Masyarakat Terhadap Pemanfaatan Pelayanan Posyandu Di Desa Pemecutan Kelod Kecamatan Denpasar Barat. Jurnal Dunia Kesehatan Vol. 5 No. 8.

Dinas Kesehatan Provinsi Bali. 2020. Adaptasi Kebiasaan Baru Di Masa Pandemi Covid-19. https://www.diskes.baliprov.go.id/adap tasi-kebiasaan-baru-di-masa-pandemicovid-19. Diakses pada 14 Pebruari 2021.

Dominski, FH. \& Brandt, R. 2020. Do the benefits of exercise in indoor and outdoor environments during the COVID-19 pandemic outweigh the risks of infection? Sport Sciences for Health.

Ikatan Dokter Anak Indonesia. 2020. Panduan Klinis Tata Laksana Covid19 Pada Anak Edisi 2. IDAI Jakarta.

Kemenkes RI. 2020. Pedoman Pelayanan Antenatal, Persalinan, Nifas, dan Bayi Baru Lahir Di Era Adaptasi Kebiasaan Baru. Jakarta: Kementerian Kesehatan RI.

Notoatmodjo, S. 2014. Ilmu Perilaku Kesehatan. Jakarta: Rineka Cipta.

Soetjingsih \& Ranuh, G. 2013.Tumbuh Kembang Anak. Edisi 2. Jakarta: EGC.

Widyana, ED, Tobiyah A, dan LPME Prani. 2015. Pola Asuh Anak dan Pernikahan Usia Dini. Jurnal Pendidikan Kesehatan. Vol. 4 No. 1, Hal. 33-39

WHO. 2021. Coronavirus disease (COVID19) advice for the public. Dapat diakses pada link:https://www.who.int/emergencies/ diseases/novel-coronavirus2019/advice-for-public 